\title{
Multiple Large Shareholder Structure and Governance: The Role of Shareholder Numbers, Contest for Control, and Formal Institutions in Chinese Family Firms
}

\section{Jin-hui Luo (罗进辉), ${ }^{1}$ Di-fang Wan (万迪昉), ${ }^{2}$ Di Cai (蔡地), ${ }^{2}$ and Heng Liu (刘衡) ${ }^{3}$}

${ }^{1}$ Xiamen University, China, ${ }^{2}$ Xi'an Jiaotong University, China, and ${ }^{3}$ Sun Yat-sen University, China

ABSTRACT The principal-principal (PP) perspective of corporate governance shows that multiple large shareholder (MLS) structure has competing monitoring and entrenchment governance effects. We argue that the dominant effect depends on contest for control among large shareholders and the number of large shareholders involved. Using data from Chinese family listed companies from 2004 to 2007, this study shows inverse $\mathrm{U}$-shaped relationships between contest for control and corporate market value, as measured by Tobin's $Q$ and between the number of large shareholders and corporate market value. Findings indicate that at low to medium levels of contest for control or number of large shareholders, formal institutions can strengthen MLS structure's monitoring effect and can help this effect last longer. As a whole, the findings extend the institution-based view in the context of family corporate governance by showing that formal institutions can shape the ability of MLS structure to exert governance.

KEYworDs China, family firms, institution-based view, multiple large shareholder (MLS) structure, principal-principal (PP) conflict

多个大股东结构与公司治理：大股东数量、控制权竞争以及正式制度的作用

摘要

公司治理领域的双委托人视角指出，多个大股东结构具有监督与暂堷两种竞争的 治理效应。本文分析认为，多个大股东结构的占优治理效应取决于大股东间的控制权筧争 程度以及大股东的个数。基于中国家族控股上市公司2004-2007年的样本数据，本文发现 控制权竞争程度与以Tobin's Q度量的公司市场价值间存在一种倒U型关系，而且这种关 系也存在于大股东个数与公司市场价值间。进一步的研究发现当控制权竞争程度 或大股东个数处于低至中等水平时, 正式的制度环境能够增强并延长多个大股东结构的 监督效应。简言之, 本文通过阐明正式的制度环境能够塑造多个大股东结构发挥治理作用的 能力，扩展了家族企业治理领域的制度基础观研究。

关键词：中国，家族企业，制度基础观，多个大股东结构，双委托人视角 


\section{INTRODUCTION}

In 1998, China's stock exchange listed the Northeast Expressway Company Ltd (stock code: SH.600003), which had a multiple large shareholder (MLS) structure in which there was intense competition for control among its large shareholders. Thus Northwest Expressway, having a relatively good governance structure, was expected to perform well. However, in 2007, the China Securities Regulatory Commission (CSRC) announced that the company needed special treatment (ST) for its weak governance and resulting bad performance. Its top three shareholders battled intensely for control rights and as a result damaged the management and daily operations. ${ }^{[1]}$ This case illustrates an inconsistency between theory and reality: apparently MLS structure sometimes fails to play a positive governance role. The purpose of this study, therefore, is to explain this contradiction in the Chinese context from the principal-principal (PP) perspective.

Recently the corporate governance literature has widely recognized that PP conflicts between majority and minority shareholders are much more significant than traditional principal-agent (PA) conflicts between shareholders and managers in emerging economies (Chang, 2003; Chen, Li, \& Shapiro, 2011; Dharwadkar, George, \& Brandes, 2000; Hu, Tam, \& Tan, 2010; Jiang \& Peng, 2011; Shleifer \& Vishny, 1997; Su, Xu, \& Phan, 2008; Young, Peng, Ahlstrom, Bruton, \& Jiang, 2008). PP conflict refers to the power majority shareholders frequently extract, in the form of private benefits, at the expense of minority shareholders (Dharwadkar et al., 2000; Hoskisson, Eden, Lau, \& Wright, 2000; Morck, Wolfenzon, \& Yeung, 2005; Su et al., 2008; Yoshikawa, Phan, \& David, 2005; Young et al., 2008). However, traditional governance mechanisms are greatly limited in addressing PP problems (Berglöf \& Pajuste, 2003; Chen et al., 201 1; Claessens \& Fan, 2002; Hu et al., 2010; Jiang \& Peng, 2011; Morck et al., 2005; Young et al., 2008). For example, Su et al. (2008) argue and find that the shareholder controlled board has become a platform for large shareholders to realize their private interests. Hence, different governance mechanisms are required to resolve PP conflicts (Chen et al., 201 1; Hu et al., 2010; Jiang \& Peng, 2011; Luo, Wan, \& Cai, 2012a; Young et al., 2008). In this context, scholars have turned increasing attention to MLS structure as an internal governance mechanism that should play an effective role in resolving PP conflicts, and have found that, indeed, MLS structure is good for corporate market value (Attig, Ghoul, \& Guedhami, 2009; Gutiérrez \& Pombo, 2009; Jiang \& Peng, 2011; Laeven \& Levine, 2008; Luo et al., 2012a; Maury \& Pajuste, 2005).

Despite some progress, the literature regarding MLS structure has at least two limitations. First, most previous studies have focused on the presence of MLS structure (e.g., Faccio, Lang, \& Young, 2001; Jiang \& Peng, 2011; Luo et al., 2012a), but ignored the effect of number of large shareholders and contest for control among multiple large shareholders. We argue that both conditions shape MLS structure's governance effectiveness. Although several recent studies 
(e.g., Attig et al., 2009; Gutiérrez \& Pombo, 2009; Maury \& Pajuste, 2005) have explored the relevance of contest for control in that governance role, there are possibilities that it may damage performance under intense competition for control. Thus, a simple positive relationship between contest for control and the effects of MLS structure's governance cannot properly explain the failure of Northeast Expressway. Our theoretical analysis prompts us to propose that a moderate level of contest for control is optimal for MLS structures to perform best in restricting large shareholders' power to expropriate minority shareholders. Additionally, the number of large shareholders may also shape MLS structure's governance role.

Second, country-/region-specific institutions with their formal and informal game rules substantially affect corporate ownership structure (Jiang \& Peng, 2011; North, 1990; Peng \& Jiang, 2010). In fact, institutional theory has shown that firms exhibit governance behaviour in response to both firm-level imperatives and country-/region-level institutions (Heugens, van Essen, \& van Oosterhout, 2009; Jiang \& Peng, 2011; Peng, Sun, Pinkham, \& Chen, 2009). Hence, standard governance models that rely on classical agency theory are being reshaped to account for institutional differences among different countries/regions that can alter governance behaviour (Su et al., 2008). Despite growing consensus that 'institutions matter', the institution-based view of corporate governance is still in its infancy (Aguilera \& Jackson, 2003; Peng \& Jiang, 2010). Specifically, few studies, if any, have considered the interaction between formal institutions and the governance role of MLS structure in solving PP conflicts.

To fill those knowledge gaps, we constructed a conceptual model that compares the three attributes of MLS structure - presence, contest for control, and number of large shareholders - with corporate market value and formal institutions. We tested this model in Chinese settings because China is the world's largest emerging economy and is reportedly experiencing severe PP conflicts (Luo et al., 2012a; Su et al., 2008; Young et al., 2008), so corporate governance research should do well by focusing on China (Fang, 2010; Tan \& Peng, 2003). So far, little is known about family ownership in China although family firms contribute greatly to China's economic growth and to the severity of PP conflicts (Allen, Qian, \& Qian, 2005; Cai, Luo, \& Wan, 2012; Ding, Zhang, \& Zhang, 2007). Hence, a focus on Chinese family firms allows us to examine the boundaries of some existing corporate governance claims to better understand China's private sector (March, 2005; Peng, Zhang, \& Li, 2007; Tsui, 2006). More importantly, China's diverse markets and geographic regions provide substantial variations in formal institutional development (Fan, Huang, Morck, \& Yeung, 2008; Fan, Wong, \& Zhang, 2005; Luo \& Peng, 1999; Peng et al., 2007). This special institutional context allows us to investigate the moderating effects of formal institutions within one country, thus mitigating potential disturbances resulting from unobserved country/region factors in cross-country studies (Fan et al., 2008). 
Using a sample of 927 firm-year observations from Chinese family listed firms from 2004 to 2007, we find that the simple presence of MLS structure is significantly associated with corporate market value, as measured by Tobin's $Q$. Yet two inverse U-shaped relationships occur between contest for control and corporate market value and between number of large shareholders and corporate market value. In addition, these three relationships are stronger in regions with higher levels of formal institutional development. These findings suggest that the governance effect of MLS structure can be contingent on the number of large shareholders, contest for control, and formal institutions. Drawing on the PP perspective and institution-based view of corporate governance, we extend the literature to enrich understanding of the role of MLS structure and the importance of formal institutions in the context of family corporate governance.

\section{THEORETICAL BACKGROUND AND HYPOTHESES}

Since the economic reform began in 1978, China has become the world's largest and fastest-growing emerging economy (Peng et al., 2007; Su et al., 2008). In three decades, China's state ownership has declined and private sector ownership has risen (Ding et al., 2007; Firth, Lin, Liu, \& Wong, 2009).

As China's economic reform has deepened, private firms have become increasingly important to the economy's rapid development (Allen et al., 2005; Cai et al., 2012; Ding et al., 2007; Firth et al., 2009). In 2009, the private sector contributed more than 50 percent of China's gross domestic product and provided more than 90 percent of new job opportunities (Huang, 2010). From 1992, with the first privately owned company listed in the Chinese stock market, a few but increasing number of privately owned firms (especially family firms) have been listed on the Shanghai and Shenzhen Chinese stock exchanges (Ding et al., 2007; Fan et al., 2005). By the end of 2007, 483 privately listed companies made up about 33.10 percent of the 1,459 listed companies. Among these, 386 (approximately 79.92 percent) were family firms controlled by entrepreneurs/ families. ${ }^{[2]}$

Similar to family firms in other emerging economies (Carney \& Gedajlovic, 2002; Claessens, Djankov, \& Lang, 2000; Jiang \& Peng, 201 1; Peng \& Jiang, 2010), most Chinese family listed companies have pyramidal structures (Cai et al., 2012; Fan et al., 2005). Controlling families usually have less than full ownership of the intermediate firms along the pyramids, so a huge divergence occurs between their cash flow and control rights (Fan et al., 2005). As Table 1 shows, in ten countries/ regions of East Asia, the pyramidal ownership structure is most common in family listed companies in mainland China (84 percent). The ratio of controlling families' ultimate cash flow rights to control rights, a reverse estimator of the divergence between ownership and control, shows the second lowest ratio in mainland China $(0.65)$ and the lowest in Japan (0.60). 
Table 1. Summary of ownership structures in family listed companies in East Asia

\begin{tabular}{|c|c|c|c|c|c|c|c|}
\hline \multirow[t]{2}{*}{ Country or region } & \multicolumn{5}{|c|}{ Mean } & \multirow{2}{*}{$\begin{array}{c}\text { Sample } \\
\text { period }\end{array}$} & \multirow[t]{2}{*}{ Reference } \\
\hline & Varl & $\operatorname{Var} 2$ & Var3 & Vart & $\operatorname{Var} 5$ & & \\
\hline \multirow{14}{*}{$\begin{array}{l}\text { Japan } \\
\text { Korca } \\
\text { Singapore } \\
\text { Indonesia } \\
\text { Malaysia } \\
\text { Philippines } \\
\text { Thailand } \\
\text { Taiwan } \\
\text { Hong Kong } \\
\text { mainland China }\end{array}$} & 0.36 & 0.07 & 0.60 & 0.10 & 0.11 & 1996 & \multirow{9}{*}{$\begin{array}{l}\text { Attig et al. (2009) } \\
\text { Claessens et al. (2000 } \\
\text { Gutiérrez and Pombe } \\
\quad(2009)\end{array}$} \\
\hline & 0.43 & 0.14 & 0.86 & 0.18 & 0.18 & 1996 & \\
\hline & 0.55 & 0.20 & 0.79 & 0.63 & 0.69 & 1996 & \\
\hline & 0.67 & 0.26 & 0.79 & 0.54 & 0.65 & 1996 & \\
\hline & 0.39 & 0.24 & 0.85 & 0.58 & 0.81 & 1996 & \\
\hline & 0.40 & 0.21 & 0.91 & 0.63 & 0.69 & 1996 & \\
\hline & 0.13 & 0.33 & 0.94 & 0.89 & 1.59 & 1996 & \\
\hline & 0.49 & 0.16 & 0.83 & 0.48 & 0.67 & 1996 & \\
\hline & 0.25 & 0.24 & 0.88 & 0.29 & 0.35 & 1996 & \\
\hline & 0.88 & 0.22 & 0.62 & 0.59 & 0.81 & 2004 & \multirow[t]{5}{*}{ This study } \\
\hline & 0.86 & 0.21 & 0.62 & 0.56 & 0.74 & 2005 & \\
\hline & 0.88 & 0.20 & 0.63 & 0.46 & 0.56 & 2006 & \\
\hline & 0.76 & 0.24 & 0.70 & 0.43 & 0.53 & 2007 & \\
\hline & 0.84 & 0.22 & 0.65 & 0.49 & 0.63 & $2004-2007$ & \\
\hline
\end{tabular}

Notes: Varl, dummy variable set to 1 if the largest shareholder excrcises control through pyramidal ownership structure, and 0 otherwise; Var2, ultimate cash flow rights of the largest shareholder, as measured by La Porta, Lopez-dc-Silancs, Shlcifer, \& Vishny (2002) method; Var3, ratio of ultimatc cash flow rights to ultimatc control rights of the largest sharcholder; Var4, dummy variable set to $I$ if at least one largc shareholder other than the largest sharcholder controls at least 10 percent voting stakes of the firm, and 0 otherwise; Var 5 , number of large sharcholders (up to fifth) other than the largest sharcholder controlling at least 10 percent voting stakes of the firm.

With information asymmetry in the capital market, a developing corporate governance regime, and China's uneven legal enforcement (Peng, 2004; Su et al., 2008), the separation of ownership and control enables and motivates controlling families to extract private benefits at the expense of minority shareholders (Attig et al., 2009; Friedman, Johnson, \& Mitton, 2003; Jiang \& Peng, 2011; Johnson, La Porta, Lopez-de-Silanes, \& Shleifer, 2000), causing severe PP conflicts.

\section{Family Ownership and MLS Structure}

In emerging economies, PP conflicts have replaced traditional PA conflicts as a major corporate governance concern (Dharwadkar et al., 2000; Jiang \& Peng, 2011; Peng \& Jiang, 2010; Shleifer \& Vishny, 1997; Su et al., 2008; Yoshikawa et al., 2005; Young et al., 2008). Governance mechanisms (e.g., markets for corporate control, managerial labour markets, boards of directors, managerial compensation), formerly designed to resolve PA conflicts, are criticized for being ineffective in resolving PP conflicts (Berglöf \& Pajuste, 2003; Chen et al., 2011; Jiang \& Peng, 2011; Young et al., 2008). In this context, researchers have argued that MLS structure acts as a potential governance mechanism that may restrict controlling families' expropriation, and thus possibly alleviate PP conflicts. We observe that MLS structure is common in emerging economies (Claessens et al., 
2000; Faccio \& Lang, 2002; Faccio et al., 2001), and thus surmise that investors may have found MLS structure to effectively counteract expropriation by controlling families. However, theoretically speaking, MLS structure has competing governance approaches to resolving PP conflicts: monitoring and entrenchment effects (Bennedsen \& Wolfenzon, 2000; Gomes \& Novaes, 2001; Zwiebel, 1995). In contrast with small shareholders who often 'vote with their feet', large shareholders have the incentive and power to monitor controlling families' tunnelling and to reduce PP conflicts (Grossman \& Hart, 1980; Jensen \& Meckling, 1976). That is, MLS structure may play a positive monitoring role. On the other hand, large shareholders also have incentives and opportunities to extract and share private benefits at the expense of minority shareholders (Bennedsen \& Wolfenzon, 2000; Gomes \& Novaes, 2001), demonstrating the entrenchment effect of MLS structure. Therefore, the monitoring effect of MLS structure may outweigh its entrenchment effect. Delving deeply into the governance mechanism of MLS structure, we argue that its net governance effect inherently depends on the levels of its contest for control and the number of large shareholders (Attig et al., 2009; Bennedsen \& Wolfenzon, 2000; Bloch \& Hege, 2001).

Moreover, scholars have recently noted that the governance effects of ownership and control structure may depend on the institutional environment (Anderson \& Reeb, 2003; Jiang \& Peng, 2011; Peng \& Jiang, 2010). Thus, scholars examining the corporate governance issue should consider the potential impact of institutional differences. Hence, the institution-based view has become one predominant theory for analyzing corporate governance issues, and can be incorporated with other classical approaches (e.g., agency theory or the PP view) to more clearly explain corporate governance issues. Scholars refer to game rules that players use when they interact (North, 2005; Ostrom, 2005), and classify institutions as informal or formal. Helmke and Levitsky (2004: 727) explained: 'informal institutions are socially shared rules, usually unwritten, that are created, communicated, and enforced outside of officially sanctioned channels. By contrast, formal institutions are rules and procedures that are created, communicated, and enforced through channels widely accepted as official'. In particular, emerging economies are undergoing economic reform and transition from informal to formal institutions (Hoskisson et al., 2000; Peng, 2003; Peng et al., 2007; Wright, Filatotchev, Hoskisson, \& Peng, 2005; Young et al., 2008). Despite a substantial increase in formal institutions (see Table 2), scholars have for a long time focused on the impact of informal institutions (e.g., guanxi, see reviews by Chen, Chen, \& Huang, 2013 and Luo, Huang, \& Wang, 2012b), and so far little is known about the role of formal institutions in China. Therefore, we focus on formal institutions, especially formal legal and regulatory institutions including courts, legislatures, corporate laws, and legal protection for private property in China. We argue that formal institutions may determine the governance effect of MLS structure in emerging economies. Developed formal institutions can improve the enforcement efficiency 


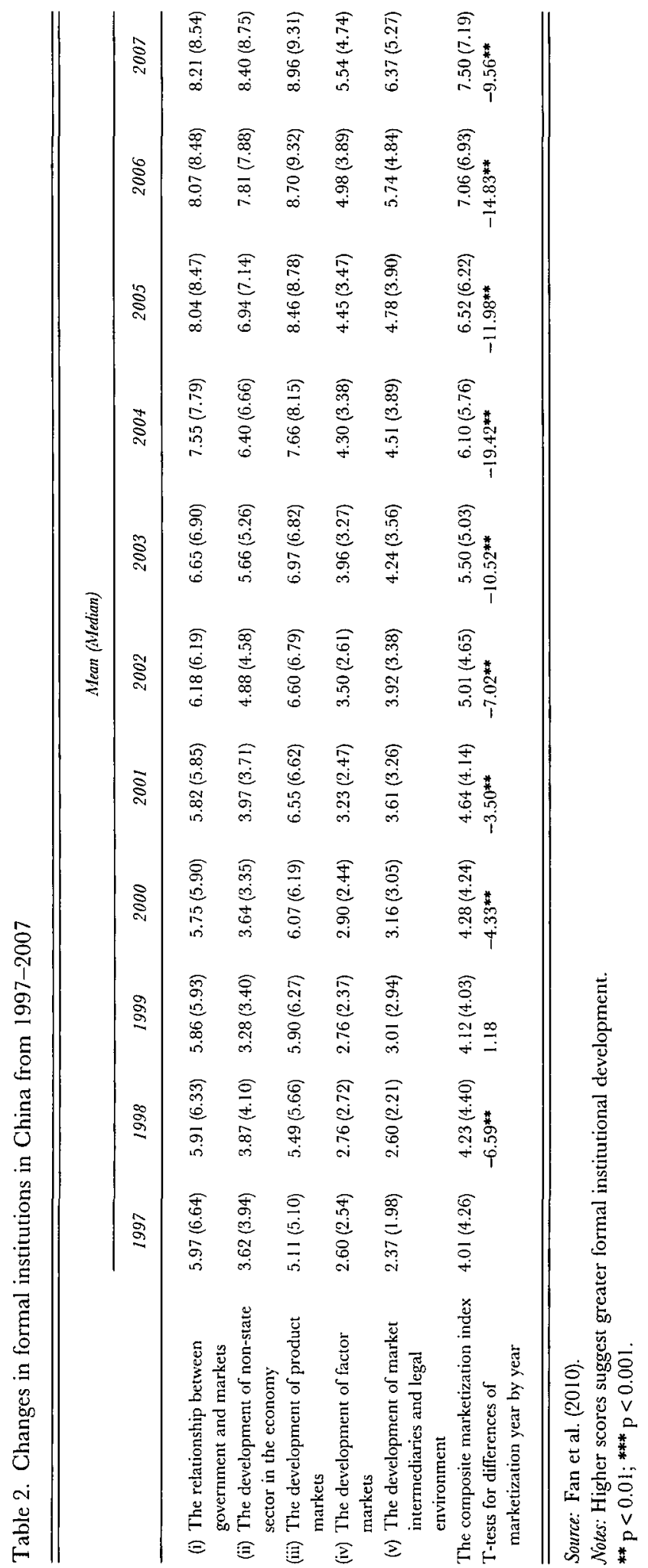

(C) 2012 The International Association for Chincse Management Research 
of monitoring contracts and may encourage large shareholders to monitor controlling families' expropriation of minority shareholders. In other words, formal institutions can strengthen the corporate governance environment for the monitoring effect of MLS structure. In addition, as external governance mechanisms, formal legal and regulatory institutions can monitor, discipline, and disarm large shareholders in their expropriation attempts (La Porta et al., 2002; Peng \& Jiang, 2010), thereby substantially moderating MLS structure's entrenchment effect.

In summary, we develop a conceptual model examining the link between MLS structure and corporate market value from the curvilinear role of contest for control and number of large shareholders, and the moderating effect of formal institutions on the MLS structure-corporate market value link.

\section{Hypotheses Development}

Presence of MLS structure. As with other emerging economies, China has weak legal investor protection, under-developed external governance mechanisms (Luo et al., 2012a; Young et al., 2008), and severe PP conflicts (Su et al., 2008). In such environments, internal governance mechanisms may be more significant ( $\mathrm{Hu}$ et al., 2010; Peng et al., 2009; Young et al., 2008). MLS structure may therefore be a useful internal mechanism for addressing PP problems (Jiang \& Peng, 2011; Luo et al., 2012a; Maury \& Pajuste, 2005).

Prior theoretical foundations have shown that MLS structure has both monitoring and entrenchment effects (Bennedsen \& Wolfenzon, 2000; Gomes \& Novaes, 2001; Zwiebel, 1995). Other large shareholders may monitor and restrict the controlling family's expropriation, so that all must collaborate to negotiate common interests (Bennedsen \& Wolfenzon, 2000; Bloch \& Hege, 2001; Jiang \& Peng, 2011; Luo et al., 2012a; Su et al., 2008). Mutual monitoring and balance, therefore, prevent expropriation of minority shareholders' interests (Jiang \& Peng, 2011; Su et al., 2008; Young et al., 2008). In the entrenchment effect, other large shareholders form a controlling coalition with the controlling family to extract and share private benefits (Attig et al., 2009; Bennedsen \& Wolfenzon, 2000; Rozeff, 1982). However, because the coalition's cash flow is greater than the controlling family's, the coalition internalizes more costs of expropriation. Hence, the coalition may expropriate less than the controlling family. In other words, despite competing effects, compared with having just a single controlling family, having multiple large shareholders may reduce PP conflicts. Therefore, we arrive at our first hypothesis:

Hypothesis 1: The presence of MLS structure will relate positively to corporate market value.

Contest for control of MLS structure. We must determine when the monitoring effect dominates the entrenchment effect. The relative strength of monitoring or 
entrenchment effects will vary under levels of contest for control. Thus we expect an inverse U-shaped relationship between contest for control of MLS structure and corporate market value.

Under low contest for control, controlling families almost completely influence the firm, can expropriate solely by their own control rights, and avoid colluding with other large shareholders (Liu, Lu, \& Song, 2009; Luo et al., 2012a; Su et al., 2008). Collusion requires controlling families to share private benefits, so chances that they will be discovered increase if they try to expropriate (Zwiebel, 1995). Other large shareholders mainly play monitoring roles in restricting controlling families, thus protecting their own investment. In other words, under low contest for control, MLS structure's net governance effect is the monitoring effect, accompanied by value premium. Thus we can expect that increased contest for control can help other large shareholders monitor and balance power (Jiang \& Peng, 2011; Maury \& Pajuste, 2005).

However, under intense competition for control, net governance has an entrenchment effect. First, because other large shareholders exert powerful counterbalances and restrictions, controlling families find it difficult to expropriate and must collude with other large shareholders to form coalitions to extract and share private benefits (Kahn \& Winton, 1998; Liu et al., 2009; Pagano \& Roell, 1998; Zwiebel, 1995), especially in emerging economies that have weak legal protection for minority investors (Young et al., 2008). Second, family or large shareholders cannot exclusively control such firms because equity holdings are evenly distributed among MLSs (Su et al., 2008). The largest shareholder finds it difficult to form a winning coalition, but various large shareholders might pursue their different objectives independently at the expense of minority shareholders. As we see in the Northeast Expressway Company case, intense battles for control are likely to emerge among MLSs for monopolizing or sharing private benefits, which may substantially damage the potential monitoring effects of MLS structure. Therefore, under intense competition for control, we expect a dominant entrenchment effect and reduced corporate market value. In addition, intense competition for control further strengthens the entrenchment effect; it enables large shareholders to form winning coalitions with a smaller equity stake or to pursue their different objectives independently, thereby externalizing the costs of expropriating minority shareholders. Thus we could expect more expropriation and more severe PP conflicts (Attig et al., 2009; Zwiebel, 1995). Thus, we present our second hypothesis:

Hypothesis 2: An inverse U-shaped relationship will occur between contest for control of MLS structure and corporate market value.

Number of large shareholders. Similar to Hypothesis 1, if a single large shareholder has control, a firm will lack sufficient supervision and balance (Jiang \& Peng, 2011; 
Pagano \& Roell, 1998; Young et al., 2008). Having more than one large shareholder may dilute the controlling family's control, prohibit expropriation, and alleviate PP conflicts (Bennedsen \& Wolfenzon, 2000; Bloch \& Hege, 2001; Su et al., 2008).

However, we cannot assume that bigger is always best. Bennedsen and Wolfenzon (2000) showed that many large shareholders make it more likely that the winning coalition of large shareholders will hold a small equity stake, thereby externalizing its action outcomes and encouraging the winning coalition to expropriate (Friedman et al., 2003; Laeven \& Levine, 2008; Rozeff, 1982). This resembles the theoretical logic in Hypothesis 2; many large shareholders often mean that equity holdings are evenly distributed and the structure has intense competition for control. Thus MLS structure can best monitor and resolve PP conflicts with a moderate number of large shareholders, bringing us to our third hypothesis:

\section{Hypothesis 3: An inverse U-shaped relationship will occur between the number of large} shareholders and corporate market value.

Interaction effects between MLS structure and formal institutions. Internal governance mechanisms need formal institutions to create good corporate governance environments (Dharwadkar et al., 2000; Peng, 2004; Wright et al., 2005; Young et al., 2008). Weak formal institutional conditions make it problematic and costly to monitor and enforce contracts (North, 1990; Wright et al., 2005; Young et al., 2008). Dyck and Zingales (2004) estimated private benefits extracted by controlling shareholders in 39 countries and found lower private benefits were associated with more developed legal and extra-legal mechanisms, indicating that formal institutions effectively curb PP conflicts. Emerging economies are known to have weak or underdeveloped formal institutions (Young et al., 2008). Table 2 shows that the marketization index, a commonly accepted measure of formal institution development in China, significantly and progressively improves from 1997 to 2007. Hence, scholars cannot ignore the potential effects of formal institutions on PP conflicts in emerging economies (Young et al., 2008).

Stronger formal institutions can strengthen the monitoring effect by representing effect and predictable rules of law that make MLS structure governance more efficient, in turn enhancing the corporate governance environment (Dharwadkar et al., 2000; La Porta et al., 2002; Suhomlinova, 2006; Young et al., 2008). Efficiency and the cost of enforcing monitoring contracts are closely related to the institutional context (Peng, 2003; Young et al., 2008). Immature institutional development makes enforcing monitoring contracts in emerging economies more costly and problematic (North, 1990; Wright et al., 2005; Young et al., 2008). Generally, stronger formal institutions can reduce MLS structure's monitoring costs, improve its monitoring efficiency, and strengthen its monitoring effect. On the other hand, stronger formal institutions can alleviate the entrenchment effect. 
Large shareholders exhibit opportunistic behaviour in response to both firm-level imperatives and country-/region-level institutions (Heugens et al., 2009; Jiang \& Peng, 2011; Peng et al., 2009), and the scale and scope of expropriation varies according to protection afforded by formal legal and regulatory institutions (Dyck \& Zingales, 2004; Jiang \& Peng, 201 1; La Porta et al., 2002; Peng \& Jiang, 2010). That is, formal institutions may be an external mechanism that protects minority shareholders (Jiang \& Peng, 201 l; La Porta et al., 2002) alleviating the entrenchment effect. Therefore:

Hypothesis 4a: The positive relationship between MLS structure and corporate market value will be stronger for firms operating in environments with higher levels of formal institutions.

As discussed in Hypothesis 2, monitoring and entrenchment effects influence the overall impact of contest for control on corporate market value. Hence, formal institutions will moderate the overall impact of contest for control on corporate market value depending on how formal institutions affect monitoring vis-à-vis entrenchment effects. Following the arguments in developing Hypothesis $4 \mathrm{a}$, in emerging economies stronger formal institutions may strengthen the monitoring effect but alleviate the entrenchment effect. Hence:

Hypothesis 4b: For firms operating in environments with higher levels of formal institutions, formal institutions will positively moderate the relationship between contest for control of MLS structure and corporate market value. Specifically, the inverse $U$-shaped relationship will show a stronger positive side and a weaker negative side.

Hypothesis 4c: For firms operating in environments with higher levels of formal institutions, formal institutions will positively moderate the relationship between the number of large shareholders and corporate market value. Specifically, the inverse U-shaped relationship will show a stronger positive side and a weaker negative side.

Figure 1 illustrates our theoretical framework with all hypotheses.

\section{METHOD}

\section{Data and Sample}

We collected data on all family listed companies from the China Stock Market \& Accounting Research (CSMAR) database (http://www.gtarsc.com). We classified family listed firms as those in which individuals or families are the largest shareholders with at least 10 percent voting rights (Le Breton-Miller \& Miller, 2009; Peng \& Jiang, 2010). Following La Porta et al. (2002), we traced firm ownership to the ultimate owners whose voting rights equalled the sum of the minimum voting stakes along the control chains. We hand-collected data about control chains of 


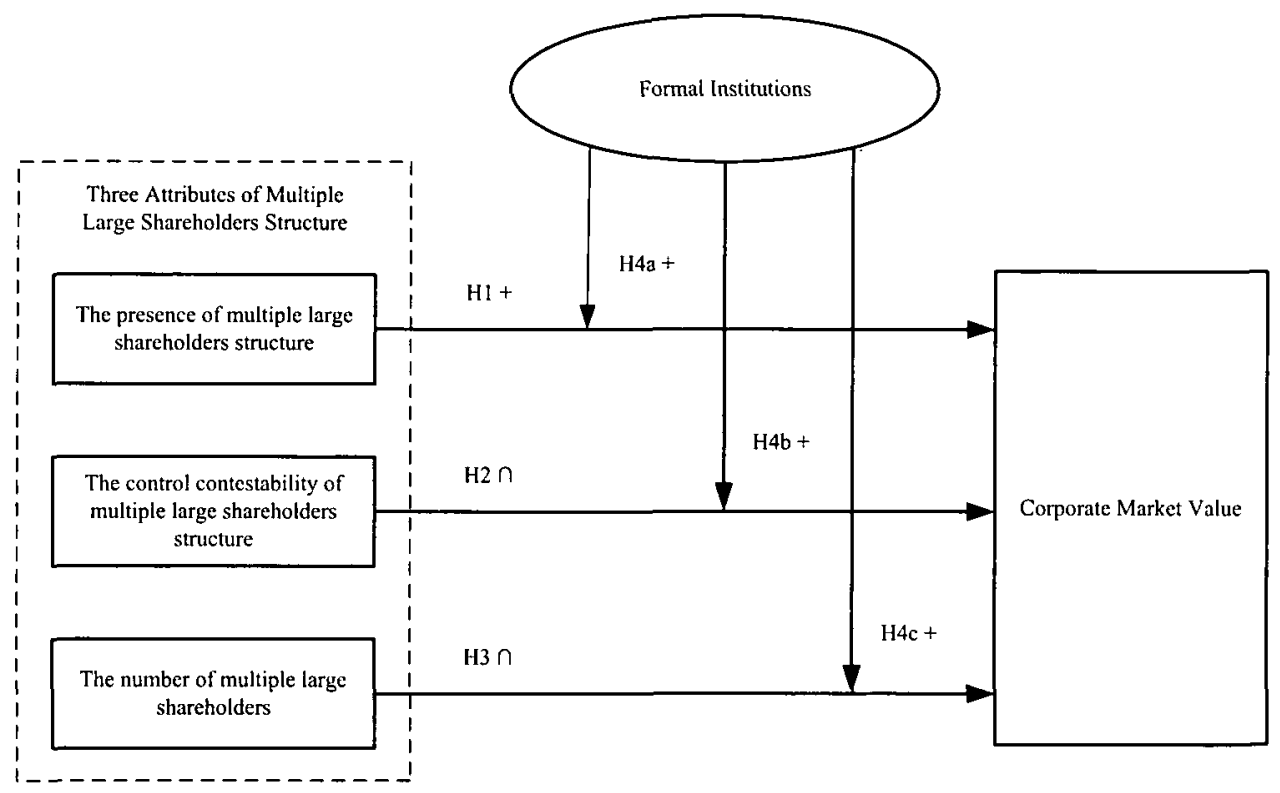

Figure 1. The theoretical framework for all hypotheses in this study

listed firms from their annual reports disclosed on the CNINFO website (http:// www.cninfo.com.cn), appointed by the CSRC. Our data on formal institutions across regions in China came from the National Economic Research Institute's (NERI) marketization index (Fan, Wang, \& Zhu, 2010).

Most Chinese listed companies began disclosing details about control chains in block diagram format in 2004. Data were available for NERI's marketization index from 1997 and 2007, so we took 2004 as our initial sample year and selected firm-year observations from 2004 to 2007, excluding firms that were financial, had missing data, were in a state of ST, had issued debt exceeding asset value, or were listed on another market in addition to the Chinese stock market. Our final sample included 379 family listed firms and 927 firm-year observations. Firms in each sample year from 2004 to 2007 numbered 162, 183, 268 , and 314 , respectively.

\section{Measures}

Dependent variable. Tobin's $Q$ is frequently used to measure a listed company's market value (Anderson \& Reeb, 2003; Yeh, 2005), so we followed this tradition and used it to measure corporate market value as the dependent variable, denoted by Tobinq. The stock of Chinese listed companies is classified as tradable and non-tradable, in which market price is only about 20 to 30 percent of tradable stocks (Chen \& Xiong, 2002). Following Bai, Liu, Lu, Song, and Zhang (2004) and Tian and Estrin (2008), we calculated Tobing as the ratio of the market value of 
equity plus the book value of debt over the book value of total assets, taking 30 percent of tradable stocks' market price as non-tradable stocks' market price..$^{[3]}$

Independent variables. We used three attributes of MLS structure - presence, contest for control, and number of large shareholders - to fully capture the governance effects of MLS structure on corporate market value. MLS structure was measured by a dummy variable, denoted by Blocks_dummy, which takes the value of 1 if the share of the second largest shareholder is at least 5 percent (Chen, Firth, \& Xu, 2009; Jiang \& Peng, 2011) ${ }^{[4]}$ Based on Hypothesis 1, we expected this variable to positively affect corporate market value.

We took the ratio of the sum of voting rights of the second to fifth largest shareholders over voting rights of the largest shareholder to measure contest for control (Attig et al., 2009; Gutiérrez \& Pombo, 2009; Liu et al., 2009), denoted as Contesll, which captures the relative strength between voting rights of the largest shareholders and the other large shareholders. Also, we took the sum of the squares of the differences between the second and third largest voting stakes, the third and fourth largest voting stakes, and the fourth and fifth largest voting stakes to measure the contest for control of the largest shareholder by other large shareholders (Attig et al., 2009; Maury \& Pajuste, 2005), denoted as Contest2, which captures the distribution of voting rights among other large shareholders. As a result, we had two alternative measures ${ }^{[5]}$ Contest 1 and Contest2, for contest for control. All else being equal, the higher both alternative variables, the higher the contest for control of the largest shareholder by other large shareholders. Based on Hypothesis 2, we expected to find two inverse U-shaped relationships between both variables and corporate market value.

Following Attig et al. (2009), we added the number of second to fifth largest shareholders with at least 5 percent ownership of the firm to measure the number of large shareholders, denoted by Blocks_number. ${ }^{[6]}$ Based on Hypothesis 3, an inverse $\mathrm{U}$-shaped relationship will occur between this variable and corporate market value.

Moderating variable. The moderating variable is the level of China's regional formal institutions. We took the NERI's marketization index to measure formal institutional development across regions (Fan et al., 2010), ${ }^{[]]}$an index many empirical studies have used to measure China's regional formal institutional development (e.g., Li, Yue, \& Zhao, 2009; Wang, Wong, \& Xia, 2008). Higher index scores suggest greater formal institutional development.

Control variables. As with previous studies (e.g., Bai et al., 2004; Chen et al., 2009) on corporate market value, we controlled factors that may systematically relate to corporate market value.

The first factor is Firm size (measured as the natural log of total assets). Smaller firms are less diversified and yield lower diversification discounts (Claessens, 
Djankov, Fan, \& Lang, 2002). Firm size and corporate market value should therefore show a negative relationship.

The second factor, Leverage, is measured as the ratio of total debt and total assets. Because commercial banks in China are currently under severe budget constraints, controlling shareholders usually use debt financing to acquire more resources to expropriate (Pan \& Yu, 2010). Thus, we expect leverage and corporate market value to show a negative relationship.

The third factor is Tangible assets, measured as the ratio of tangible assets and total assets. Lower asset tangibility suggests that intangibles (know-how, branding) are generating a firm's cash flows, implying high corporate market value (Gutiérrez $\&$ Pombo, 2009). Therefore, we expect this variable and corporate market value to have a negative relationship.

Sales growth, the fourth factor, is measured as the change ratio in sales yearon-year. This variable proxies for growth prospects and investment, and is pivotal for better performance (Claessens et al., 2002; Yoshikawa \& Rasheed, 2010). We expect this variable and corporate market value to have a positive relationship.

Finally, we created 12 industry dummies (omitting the financial industry) according to Guidelines for Classification of Listed Companies issued by the CSRC (A through M), and four-year dummies for 2004 to 2007.

\section{The Model}

Preliminary analyses of panel data reveal expected heteroskedasticity but not autocorrelation dependent variables problems. Referring to Greene (1993) and Su et al. (2008), we conducted feasible generalized least squares (FGLS) regressions with heteroskedastic but uncorrelated error structure (Canarella \& Gasparyan, 2008) to test our hypotheses. Multicollinearity appears insignificant, because the average variance inflation factor (VIF) for each regression model is less than three. In addition, we centered the interaction variables to avoid multicollinearity. We also conducted the Durbin-Wu-Hausman (DWH) chi-square test for endogeneity between corporate market value and MLS structure variables. ${ }^{[8]}$ The results fail to reject the null hypothesis of no endogeneity, indicating that our four variables are exogenous and our FGLS regression model is efficient.

As a robustness check, we also conducted OLS regressions and found qualitatively similar results. In the next section, therefore, we report only results from the FGLS models.

\section{RESULTS}

Table 3 reports descriptive statistics on the family listed firms in our sample. In the total sample, 71 percent of firms have a second largest shareholder with 5 percent 


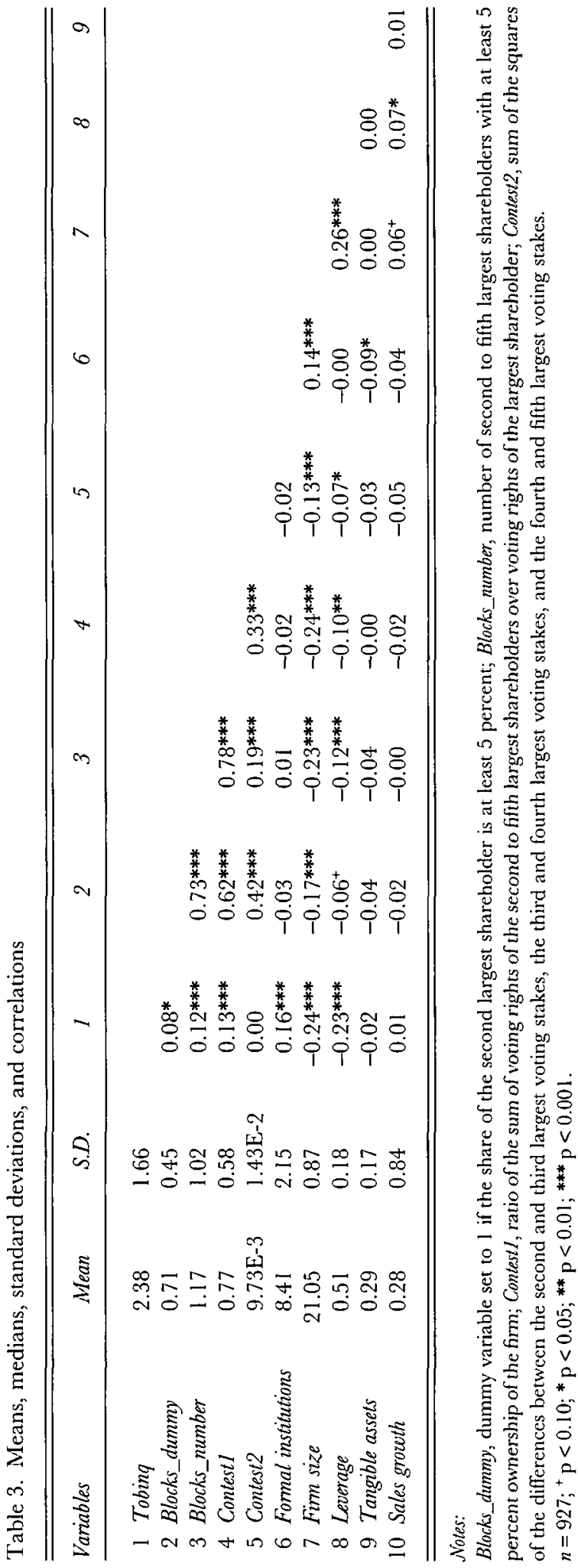

(C) 2012 The International Association for Chinesc Management Rescarch 
voting stakes, indicating that MLS structure is common. On average, we find a 0.77 ratio for the sum of voting rights of second to fifth largest shareholders over the largest shareholder. The less-than-1 ratio reflects that families highly control voting stakes. We find an average of 1.17 in the number of large shareholders, also indicating that MLS structure is common. Average ratios of tangible assets and sales growth are both close to 0.30 , suggesting high growth probabilities.

Table 3 also presents the correlation coefficients of the variables included in the regression models. It shows a high correlation for our four independent variables Blocks_dummy, Blocks_number, Contest1, and Contest2. For example, the correlation coefficient between the presence of MLS structure (Blocks_dummy) and the number of large shareholders (Blocks_number) is 0.73 , much greater than 0.5. However, the correlation coefficients between each of our four independent variables and control variables are all much less than 0.5 . Hence, we separately included our four main independent variables in regression models.

Tables 4 to 6 show the results of FGLS regression analyses. We conducted hierarchical multiple regression to report the results. In particular, we followed Janssen's (2001) six successive steps to test the quadratic-by-linear interaction of MLS structure and formal institutions with corporate market value. The model fit for our four models, as indicated by the log likelihood ratio, improved consistently step by step. We added both industry and year indicators in all regression models (not reported here).

Hypotheses 1 and 4a pertain to the presence of MLS structure. As Table 4 shows, MLS structure (Blocks_dummy) positively affects corporate market value in all models $(p<0.001)$, and the interaction (Blocks_dummy $\times$ Formal institutions) is positive and significant (Model 1d: $\beta=0.02, p<0.05$ ). Thus, Hypotheses 1 and $4 a$ are fully supported, suggesting that MLS structure is positively related to corporate market value, and that formal institutions positively moderate this relationship.

Hypothesis 2 predicted that contest for control of MLS structure, measured by Contest 1 and Contest 2 alternatively, has an inverse U-shaped relationship with corporate market value. As Table 5 a shows, Contest 1 has a positive and significant coefficient $(\mathrm{p}<0.001)$ and Contest1 squared has a negative and significant coefficient $(p<0.001)$ in all models. Similarly, in Table $5 b$, for the alternative measure, Contest 2 has a positive and significant coefficient, and Contest 2 squared has a negative and significant coefficient. These results strongly support Hypothesis 2. Hypothesis $4 \mathrm{~b}$ also relates to contest for control of MLS structure but focuses on the moderating rolc of formal institutions. The results show that for Contest 1 (Table 5a: model 21 ), the first-order interaction (Contest $1 \times$ Formal institutions) is significant and positive $(\beta=0.05, \mathrm{p}<0.001)$, and the second-order interaction (Contest1 squared $\times$ Formal institutions) is significant and negative $(\beta=-0.08, \mathrm{p}<0.001)$; for Contest2 (Table 5b: model 31), the first-order interaction (Contest $2 \times$ Formal institutions) is significant and positive $(\beta=1.76, \mathrm{p}<0.001)$, and the second-order interaction (Contest2 squared $\times$ Formal institutions $)$ is significant and negative $(\beta=-33.03, \mathrm{p}<0.05)$. These 


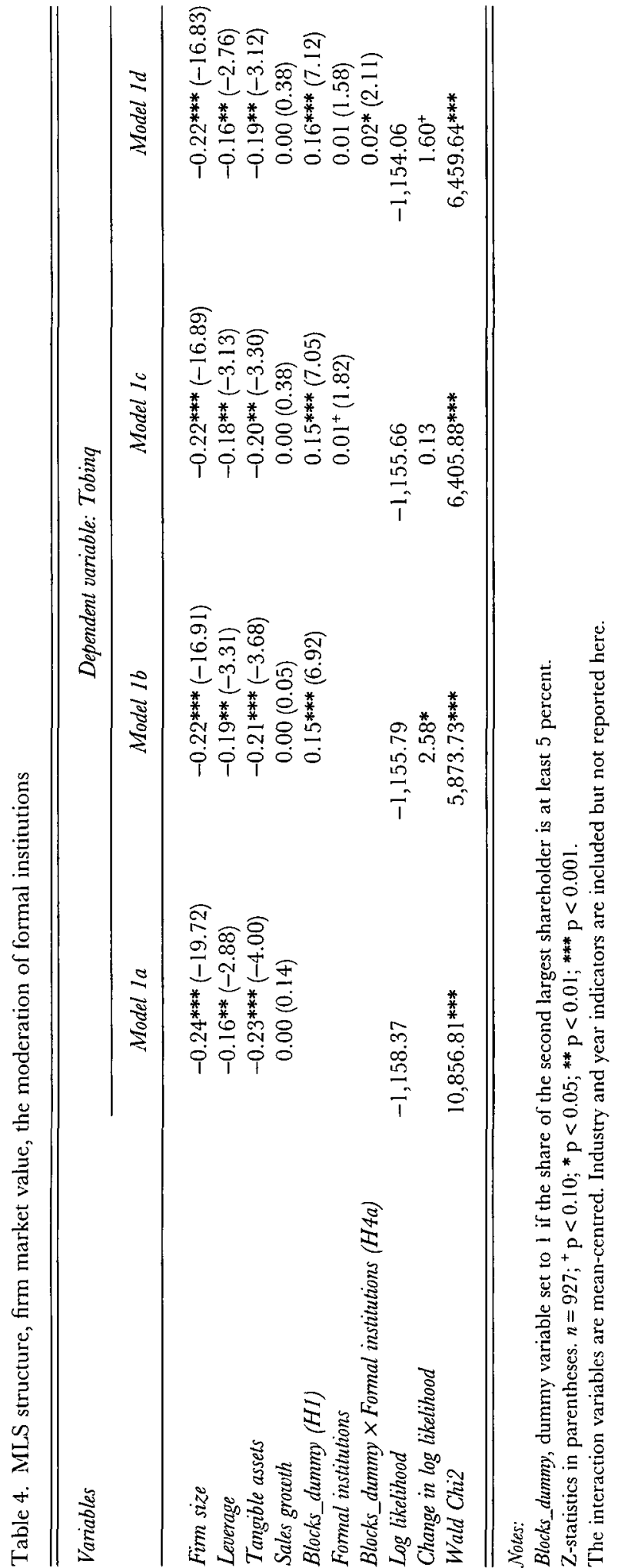

(C) 2012 The International Association for Chinese Management Research 


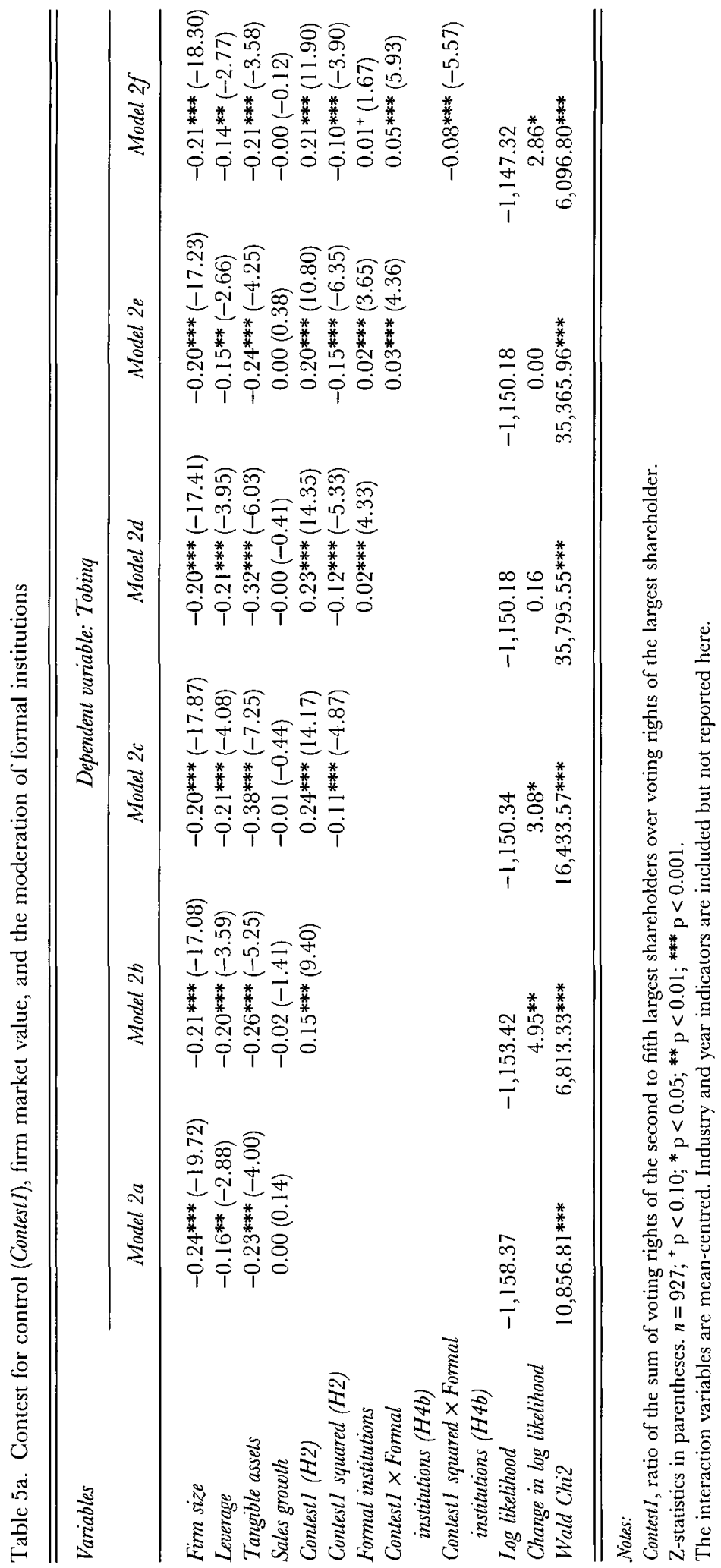




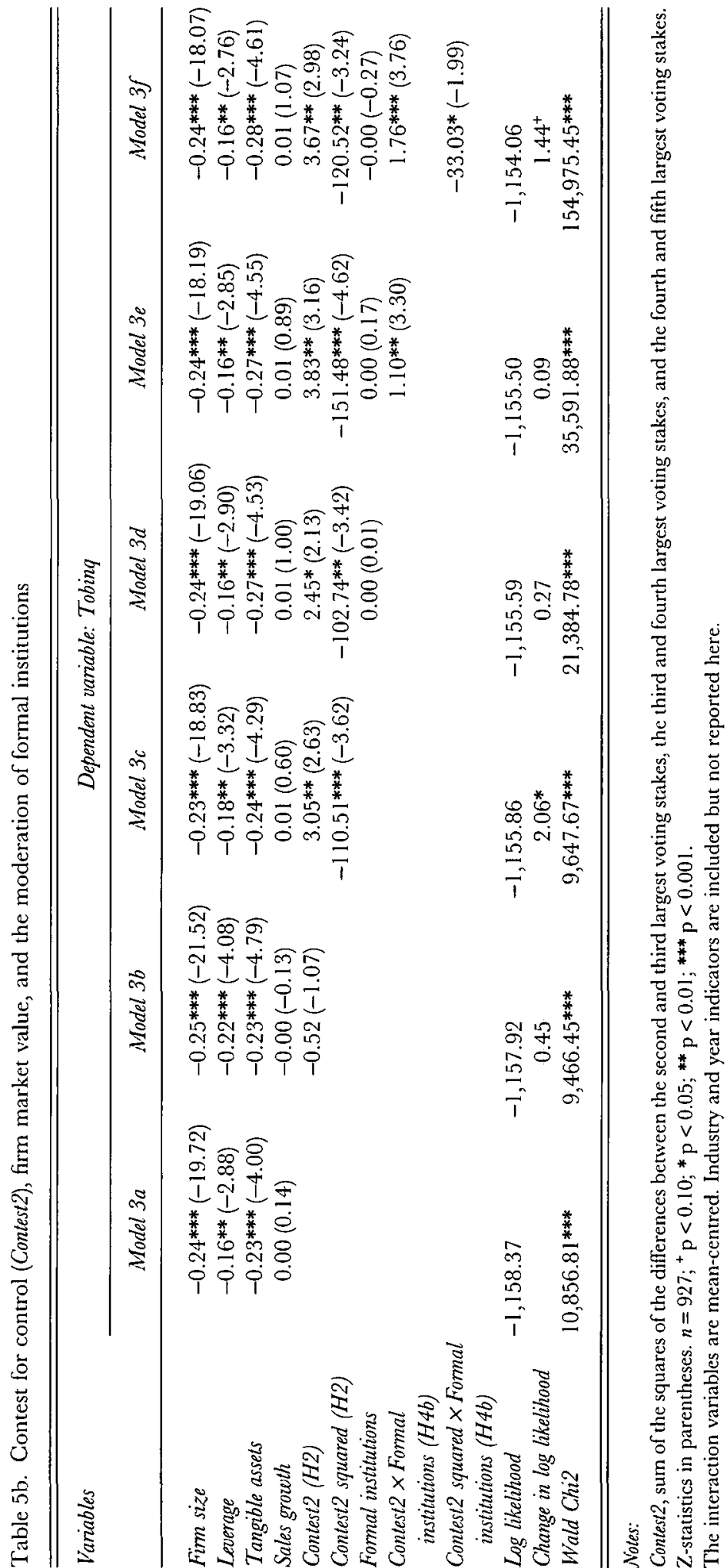

(C) 2012 The International Association for Chinese Management Research 


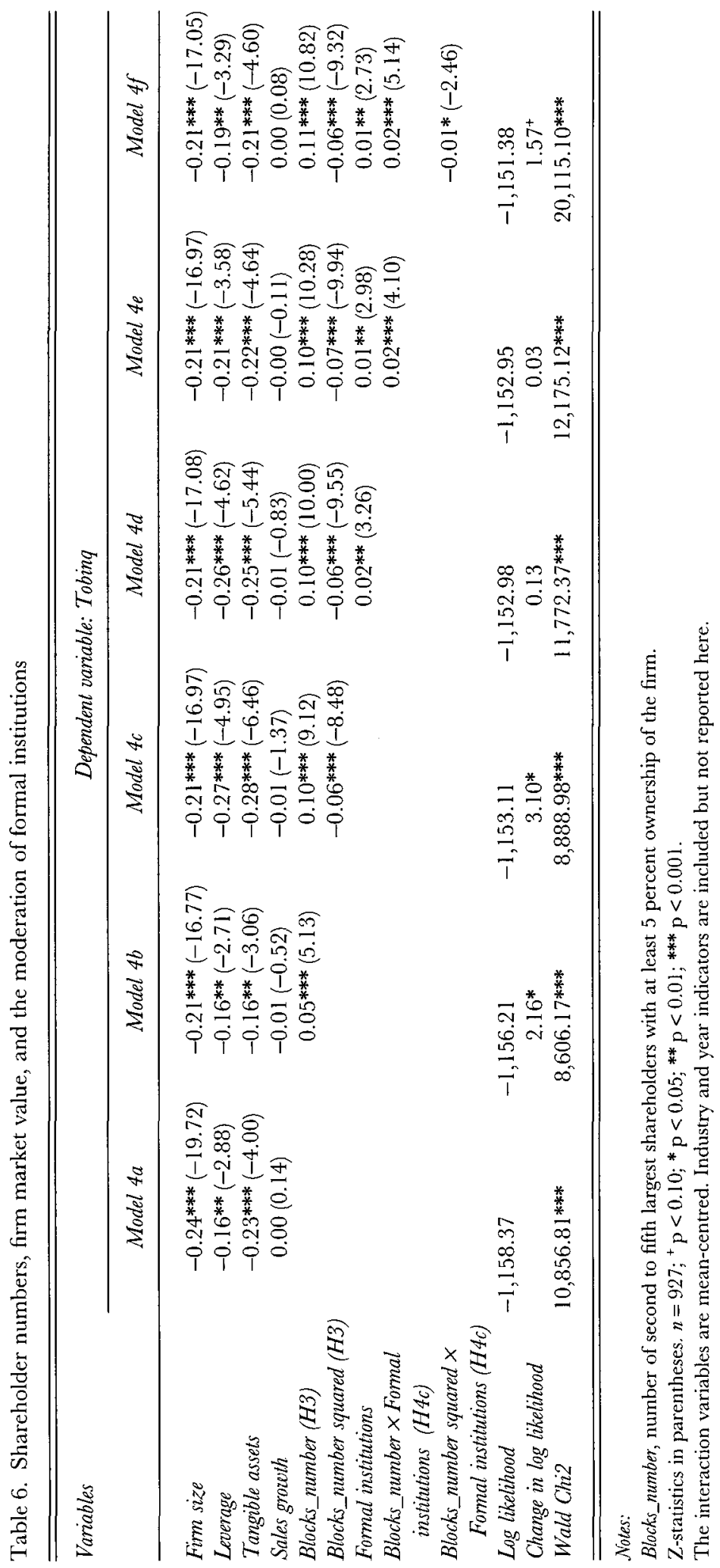


results are consistent with Hypothesis $\mathrm{H} 4 \mathrm{~b}$ : formal institutions strengthen the positive relationship on the left half of the inverse U-shaped relationship between contest for control and corporate market value, whereas formal institutions also strengthen the negative relationship on the right half of the inverse U-shaped relationship, which only partially supports Hypothesis $4 \mathrm{~b}$.

Hypotheses 3 and $4 \mathrm{c}$ relate to the number of large shareholders. For Hypothesis 3, we posited that the number of large shareholders, Blocks_number, has an inverse U-shaped relationship with corporate market value. As Table 6 shows, Blocks_number is positively and significantly related to corporate market value $(p<0.001)$, while Blocks_number squared is negatively and significantly related to corporate market value $(\mathrm{p}<0.001)$ in all models, supporting Hypothesis 3. For Hypothesis $4 \mathrm{c}$ (Table 6: model 41), the first-order interaction (Blocks_number $\times$ Formal institutions) is positive and significant $(\beta=0.02, \mathrm{p}<0.001)$, and the second-order interaction (Blocks_number squared $\times$ Formal institutions) is negative and significant $(\beta=-0.01$, $\mathrm{p}<0.05$ ). Hence, we found that formal institutions strengthen the positive effect of the number of large shareholders when the number is relatively small and the negative effect when the number is large, partially supporting Hypothesis $4 \mathrm{c}$.

To study interaction effects, we followed Aiken and West (1991) and Li, Poppo, and Zhou (2008), decomposed the interaction terms, and then plotted the relationships between our four variables of MLS structure and corporate market value. We split our sample into two groups according to the level of formal institutions low (below the median) and high (above the median), and then estimated the effects of MLS structure variables on corporate market value for both levels. For convenient figure plotting, we constrained all control variables to their mean values and transformed the mean-centered variables to their initial values $(\mathrm{Li}, \mathrm{Guo}, \mathrm{Yi}, \& \mathrm{Liu}$, 2010). Then we obtained the regression functions for the relationships between MLS structure variables and corporate market value. Based on the regression functions, we drew four connected line plots: Figure 2a for the presence of MLS structure; Figures 2b and $\mathrm{c}$ for two alternative measures of contest for control; and Figure $2 \mathrm{~d}$ for the number of large shareholders.

As Figure 2a illustrates, at high formal institution levels, the valuation premium of MLS structure increases more rapidly, suggesting that formal institutions strengthen the positive effect of MLS structure on corporate market value, thereby supporting Hypothesis 4a. Figure $2 \mathrm{~b}$ and $\mathrm{c}$ show stronger positive relationships between contest for control and corporate market value on the left side of the inverse $\mathrm{U}$-shaped relationship and stronger negative relationship on the right side of the curve, partially supporting Hypothesis $4 \mathrm{~b}$. Figure $2 \mathrm{~d}$ similarly depicts formal institutions' moderating effect on the relationship between the number of large shareholders and corporate market value. Figure $2 b$, c, and d show clearly that both positive effect of contest for control and positive effect of number of large shareholders on corporate market value endure longer under high levels of formal institutions. In other words, MLS structure has greater and longer-lasting positive 

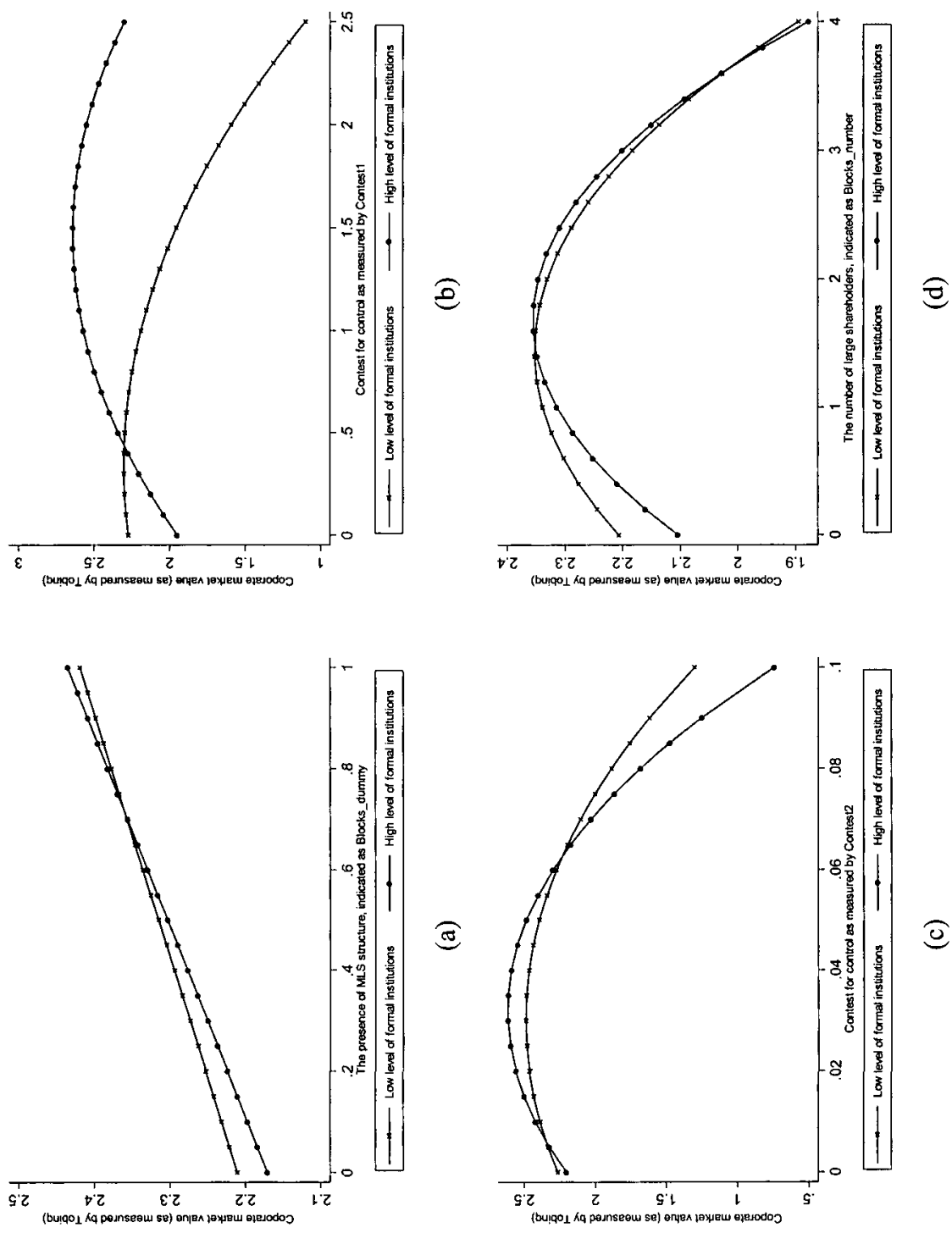

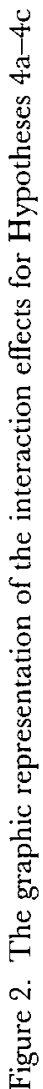


effect on corporate market value for firms operating in environments that feature more formal institutions.

\section{DISGUSSION}

Our study offers three contributions. First, we join the ongoing research into the PP perspective of corporate governance in emerging economies (Chen \& Young, 2010; Jiang \& Peng, 2011; Luo et al., 2012a; Peng \& Jiang, 2010; Su et al., 2008; Young et al., 2008). We focus on multiple-large-shareholder structure as an internal governance mechanism for resolving PP conflicts. Combining competing governance effects of multiple-large-shareholder structure - the monitoring effect and the entrenchment effect - we argue that MLS structure does not always alleviate PP conflicts and thus enhances corporate market value. Specifically, the net governance effect of multiple-large-shareholder structure depends on its level of contest for control and the number of large shareholders. Our findings, based on data from Chinese family listed companies, strongly support our argument and suggest two inverse U-shaped relationships between contest for control and corporate market value and between the number of large shareholders and corporate market value. Overall, this study expands and deepens our understanding of the governance role of multiple-large-shareholder structure in resolving severe PP conflicts in emerging economies.

Second, responding to calls for more in-depth work on comparative institutional analysis of corporate governance in emerging economies (Aguilera \& Jackson, 2003; Peng \& Jiang, 2010; Su et al., 2008; Young et al., 2008), we explore the impact of formal institutions on shaping the governance role of multiple-largeshareholder structure. Based on data from China's diverse markets and geographic regions, we find that formal institutions strengthen and extend the positive monitoring effect of multiple-large-shareholder structure on corporate market value. However, in contrast with our hypotheses and previous findings (e.g., Dyck \& Zingales, 2004; Jiang \& Peng, 201 1; La Porta et al., 2002; Peng \& Jiang, 2010), when the net governance effect is entrenchment, formal monitoring situations fail to alleviate the negative effect on corporate market value; instead formal institutions strengthen the negative effect. As the government develops more formal institutions, outside investors, especially minority shareholders, believe they are protected and may monitor large shareholders less actively, inducing large shareholders to extract more private benefits. Emerging economies still have weaker and fewer formal institutions as compared with developed economies (Jiang \& Peng, 2011; Morck et al., 2005; North, 1990; Peng \& Jiang, 2010; Wright et al., 2005; Young et al., 2008). As a result, large shareholders may take advantage of the 'strong' legal protections for minority shareholders and extract more private benefits. For example, in China, boards of directors are established to improve corporate legality, but they frequently serve as platforms that allow large shareholders 
to enhance their private interests (Su et al., 2008). Although emerging economies have immature formal institutions, not yet able to play external governance roles alone, they may help multiple-large-shareholder structure play a more effective governance role as an internal mechanism. Broadly speaking, this study extends the institution-based view in the context of family corporate governance and reveals the importance of formal institutions in shaping the governance role of multiple-large-shareholder structure in emerging economies.

Finally, we use data from Chinese family listed companies to describe and compare family ownership and control in China. We enrich the growing map of worldwide family ownership structures (Claessens et al., 2000; La Porta et al., 2002). In China, controlling families use pyramidal ownership structures much more frequently than do most emerging economies. This means a huge divergence of ownership and control and severe PP conflicts. Meanwhile, multiple-largeshareholder structure is common in Chinese family listed companies and can play an effective governance role in alleviating PP conflicts under certain conditions. Overall, our focus on PP conflicts in Chinese family listed firms represents relatively novel research suggesting several insightful indications for improving corporate governance and corporate market value in China.

\section{Limitations and Future Research Directions}

Despite these contributions, we recognize that future research should address several limitations of this study. First, we did not explore the impact of the identity of large shareholders although different types of large shareholders may have distinct professional abilities, resources, and incentives to monitor controlling families (Attig et al., 2009; Jiang \& Peng, 2011; Luo et al., 2012a; Maury \& Pajuste, 2005), whereas other types of large shareholders may be more likely to extract private benefits (Villalonga \& Amit, 2006). Thus, future research should address the impact of large shareholder identities. Generalizability is another limitation. Does the Chinese context bias our conclusions? Although China is an emerging economy, its institutional context differs from other emerging economies such as Russia or India, and may yield different outcomes (Leung, 2012; Young et al., 2008). Future work should examine the boundaries of our arguments and conclusions across various emerging economies. Finally, the institution-based view of corporate governance and family business in emerging economies remains in its infancy (Aguilera \& Jackson, 2003; Peng \& Jiang, 2010; Peng et al., 2009). This calls for more in-depth research for better understandings of family corporate governance in emerging economies.

\section{Practical Implications}

We provide a convenient and reliable approach to detect PP costs. Outside investors can use the visible and reliable information about MLS structure presented in 
our study to help them make wiser investments. All else being equal, compared with firms having one single large shareholder, firms with MLSs are much better investments. For family owners and policymakers who aspire to improve corporate governance and value, we suggest that introducing institutional investors establishes MLS structure, which reduces the likelihood of controlling families expropriating. But we cannot assume the more institutional investors the better. Without effective legal protection for investors, institutional investors may collude with controlling families to extract and share private benefits of control, especially when voting stakes are evenly distributed among too many large shareholders. Meanwhile, policymakers should strengthen formal institutional environments to help MLS structure exert a stronger and longer-lasting monitoring effect. Furthermore, our findings suggest that regulators (e.g., CSRC in China) should particularly focus on supervising family firms that have one single large shareholder or firms that have too many large shareholders.

\section{GONCLUSION}

Multiple large shareholder structure has been recognized as an important internal governance mechanism for resolving principal-principal conflicts in emerging economies. However, inspired by a real case from China, we argue that the governance effect of multiple large shareholder structure is sometimes flawed. Its value depends on contest for control among large shareholders, number of large shareholders, and formal institutions. Based on data from Chinese family listed companies from 2004 to 2007 , we find two inverse U-shaped relationships betwcen contest for control and corporate market value and between number of large shareholders and corporate market value. Moreover, high levels of formal institutions can help multiple large shareholder structure play a stronger and longerlasting monitoring role. Overall, by drawing on the principal-principal perspective and the institution-based view of corporate governance, we add to the literature on corporate governance, especially family corporate governance, in emerging economies.

\section{NOTES}

We thank Senior Editor Professor Yadong Luo, Editor-in-Chief Professor Anne Tsui, and two anonymous rcvicwers for their insightful comments and suggestions. We are grateful to Professor Mike W. Peng for his help on drafts. This research was partly supported by the Chinese National Science Funds (Grant no. 71202061, 71202093, and 70972101), the Postdoctoral Science Foundation of China (Grant no. 2011 M500136), and Fujian Provincial Social Science Planning Youth Project (Grant no. 2012C027). All views expressed are those of the authors and not of the sponsoring organizations.

[1] For more detailed information about this case, see http://www.21 cbh.com/HTML/2010-2-1/ 164486.html (in Chinese).

[2] The data were collected from the CSMAR database and hand consolidated. 
[3] On April 29, 2005, the Chinese government initiated split share structure reform to convert non-tradable shares to tradable shares. While still ongoing, this reform was basically completed at the end of 2006. Because non-tradable shares will be freely traded on the stock market soon, their market price will undoubtedly become much higher and even near the price of tradable shares. Thus, we take tradable stocks' price as a proxy of non-tradable stocks' price and acquire an alternative measurement of Tobin's $Q$. Based on this measure, we found similar empirical results (not reported in this study).

[4] Company law in China provides shareholders who have at least 5 percent ownership the right to make new proposals, which helps other large shareholders who are struggling against the controlling shareholder's efforts to expropriate minority investors. We took 5 percent as a cut-off point to define large shareholders. Simultaneously, as a robustness check, we also tried 10 percent as a cut-off point and found similar results (not reported in this study).

[5] For robustness checks, we also tried alternative measurements of contest for control of MLS structure such as HI_differences, HI_concentration, and Shapley value that have been used in prior literature (Attig et al., 2009; Gutiérrez \& Pombo, 2009; Maury \& Pajuste, 2005). We found consistent results (not reported in this study) for these alternative measures. Therefore, our findings are not limited to the measure of contest for control.

[6] Even if the number of large shareholders excludes the largest shareholder, the relationship between the number of large shareholders and corporate market value is inherently the same.

[7] Specifically, the marketization index captures the regional market development of: (1) relationship between government and markets; (2) non-state sector in the economy; (3) product markcts; (4) factor markets; and (5) market intermediaries and legal environment. These aspects include 23 components. Using 1999 as the base year, the minimum and maximum values for cach component are specified to be 0 and 10, respectively. Values of cach component in other ycars are normalized by the corresponding base-year values. The final marketization index is an average of these 23 components. For further related information, sec Fan et al. (2010).

[8] The DWH test should be conducted after instrumental variables (IV) regression, so we instrumented our four variables of MLS structure by their lagged value (Anderson \& Reeb, 2003), and then employed the IV-2SLS regression model.

\section{REFERENCES}

Aguilera, R., \& Jackson, G. 2003. The cross-national diversity of corporate governance: Dimensions and determinants. Academy of Management Reviez, 28(3): 447-465.

Aiken, L. S., \& West, S. G. 1991. Multiple regression: Testing and interpreting interactions. Newbury Park, CA: Sage.

Allen, F., Qian, J., \& Qian, M. 2005. Law, finance, and cconomic growth in China. Joumal of Financial Economics, 77(1): 57-116.

Anderson, R. C., \& Reeb, D. M. 2003. Founding-family ownership and firm performance: Evidence from the S\&P 500. Journal of Finance, 58(3): 1301-1328.

Attig, N., Ghoul, S. E., \& Guedhami, O. 2009. Do multiple large sharcholders play a corporate governance role: Evidence from East Asia. Joumal of Financial Research, 32(4): 395-422.

Bai, C. E., Liu, Q., Lu, J., Song, F. M., \& Zhang, J. 2004. Corporate governance and market valuation in China. Joumal of Comparative Economics, 32(4): 599-616.

Bennedsen, M., \& Wolfenzon, D. 2000. The balance of power in closely held corporations. Journal of Financial Economics, 58(1/2): 113-139.

Berglöf, E., \& Pajuste, A. 2003. Emerging owners, eclipsing markets? Corporate governance in Central and Eastern Europe. In P. K. Cornclius \& B. Kogut (Eds.), Corporate governance and capital flows in a global economy: 267-303. Oxford: Oxford University Press.

Bloch, F., \& Hege, U. 2001 . Multiple shareholders and control contests. Working Paper, Aix-Marscille University.

Cai, D., Luo, J.-H., \& Wan, D.-F. 2012. Family CEOs: Do they benefit firm performance in China? Asia Pacific Joumal of Management, 29(4): 923-947.

Canarella, G., \& Gasparyan, A. 2008. New insights into executive compensation and firm performance: Evidence from a panel of 'new cconomy' firms, 1996-2002. Managerial Finance, 34(8): $537-554$. 
Carney, M., \& Gedajlovic, E. 2002. The coupling of ownership and control and the allocation of financial resources: Evidence from Hong Kong. Joumal of Management Studies, 39(1): $123-146$.

Chang, S. J. 2003. Ownership structure, expropriation, and value of group-affliated companies in Korea. Academy of Management Journal, 46(2): 238-253.

Chen, C. C., Chen, X. P., \& Huang, S. 2013. Chinese guanxi: An integrative review and future research directions. Management and Organization Revieze, 9(1): 167-207.

Chen, G., Firth, M., \& Xu, L. 2009. Does the type of ownership control matter? Evidence from China's listed companics. Journal of Banking \& Finance, 33(1): 171-181.

Chen, V. Z., Li, J., \& Shapiro, D. M. 2011. Are OECD-prescribed 'good corporate governance practices' really good in an emerging economy? Asia Pacific Joumal of Management, 28(1): $115-138$.

Chen, Y. Y., \& Young, M. N. 2010. Cross-border mergers and acquisitions by Chinese listed companies: A principal-principal perspective. Asia Pacific Journal of Management, 27(3): 523-539.

Chen, Z., \& Xiong, P. 2002. The illiquidity discount in China. Working Paper, International Center for Financial Rescarch, Yale University, New York, USA.

Clacssens, S., Djankov, S., \& Lang, L. 2000. The separation of ownership and control in East Asian corporations. Journal of Financial Economics, 58(1): 81-112.

Claessens, S., Djankov, S., Fan, J., \& Lang, L. 2002. Disentangling the incentive and entrenchment effects of large shareholdings. Joumal of Finance, 57(6): 2741-2771.

Claessens, S., \& Fan, J. P. H. 2002. Corporate governance in Asia: A survey. Intermational Revieze of Finance, 3(2): 71-103.

Dharwadkar, R., George, G., \& Brandes, P. 2000. Privatization in emerging economies: An agency theory perspective. Academy of Management Review, 25(3): 650-669.

Ding, Y., Zhang, H., \& Zhang, J. 2007. Private vs. state ownership and earnings management: Evidence from Chinesc listed companies. Corporate Governance: An Intemational Review, 15(2): 223-238.

Dyck, A., \& Zingales, L. 2004. Private benefits of control: An international comparison. Jourmal of Finance, 59(2): 537-600.

Faccio, M., \& Lang, L. 2002. The ultimate ownership of Western European corporations. Journal of Financial Economics, 65(3): 365-395.

Faccio, M., Lang, L., \& Young, L. 2001. Dividends and expropriation. The American Economic Review, 91(1): 54-78.

Fan, G., Wang, X., \& Zhu, H. 2010. NERI Index of Marketization of China's Provinces. Beijing: Economics Science Press (in Chinese).

Fan, J. P. H., Wong, T. J., \& Zhang, T. 2005. The emergence of corporate pyramids in China. Working Paper. Hong Kong, China: The Chinese University of Hong Kong.

Fan, J. P. H., Huang, J., Morck, R., \& Ycung, B. 2008. Vertical integration, institutional determinants and impact: Evidence from China. Working Paper. Hong Kong, China: The Chinese University of Hong Kong.

Fang, T. 2010. Asian management research needs more self-confidence: Reflection on Hofstede (2007) and beyond. Asia Pacific Journal of Management, 27(1): 155-170.

Firth, M., Lin, C., Liu, P., \& Wong, S. M. L. 2009. Inside the black box: Bank credit allocation in China's private sector. Journal of Banking \& Finance, 33(6): 11441155.

Friedman, E., Johnson, S., \& Mitton, T. 2003. Propping and tunneling. Joumal of Comparative Economics, 31(4): 732-750.

Gomes, A., \& Novaes, W. 2001. Sharing of control as a corporate governance mechanism. SSRN Working Paper.

Greene, W. H. 1993. Econometric analysis. New York: Macmillan.

Grossman, S., \& Hart, O. 1980. Takeover bids, the free rider problem, and the theory of the corporation. Bell Journal of Economics, 11(1): 42-69.

Gutiérrez, L. H., \& Pombo, C. 2009. Corporatc ownership and control contestability in cmerging markets: The case of Colombia. Joumal of Economics and Business, 61(2): $112-139$.

Helmke, G., \& Lcvitsky, S. 2004. Informal institutions and comparative politics: A research agenda. Perspectives on Politics, 2(4): 725-740. 
Heugens, P., van Essen, M., \& van Oosterhout, J. 2009. Meta-analyzing ownership concentration and firm performance in Asia: Towards a more fine-grained understanding. Asia Pacific Journal of Management, 26(3): 481-512.

Hoskisson, R. E., Eden, L., Lau, C. M., \& Wright, M. 2000. Strategy in emerging economies. Academy of Management Joumal, 43(3): 249-267.

Hu, H. W., Tam, O. K., \& Tan, M. G.-S. 2010. Internal governance mechanisms and firm performance in China. Asia Pacific Joumal of Management, 27(4): 727-749.

Huang, M. 2010. Annual report of non-state-ozened economy in China No. 7 (2009-2010). Beijing: Social Sciences Academic Press (China).

Janssen, O. 2001. Fairness perceptions as a moderator in the curvilinear relationships between job demands, and job performance and job satisfaction. Academy of Management Joumal, 44(5): 1039-1050.

Jensen, M. C., \& Meckling, W. H. 1976. Theory of the firm: Managerial behavior, agency costs and ownership structure. Joumal of Financial Economics, 3(4): 305-360.

Jiang, Y., \& Peng, M. W. 2011. Principal-principal conficts during crisis. Asia Pacific Journal of Management, 28(4): 683-695.

Johnson, S., La Porta, R., Lopez-de-Silanes, F., \& Shleifer, A. 2000. Tunneling. The American Economic Revieze, 90(2): 22-27.

Kahn, C., \& Winton, A. 1998. Ownership structure, speculation, and shareholder intervention. Journal of Finance, 53(1): 99-129.

La Porta, R., Lopez-de-Silanes, F., Shleifer, A., \& Vishny, R. 2002. Investor protection and corporate valuation. Joumal of Finance, 57(3): 1147-1170.

Laeven, L., \& Levine, R. 2008. Complex ownership structures and corporate valuations. Revieze of Financial Studies, 21(2): 579-604.

Le Breton-Miller, I., \& Miller, D. 2009. Agency vs. stewardship in public family firms: A social embeddedness reconciliation. Entrepreneurship Theory and Practice, 33(6): 1169-1191.

Leung, K. 2012. Indigenous Chinese management research: Like it or not, we need it. Management and Organization Review, 8(1): 1-5.

Li, J. J., Poppo, L., \& Zhou, K. Z. 2008. Do managerial ties in China always produce value? Competition, uncertainty, and domestic vs. foreign firms. Strategic Management Joumal, 29(4): 383-400.

Li, K., Yue, H., \& Zhao, L. 2009. Ownership, institutions, and capital structure: Evidence from China. Joumal of Comparative Economics, 37(3): 471-490.

Li, Y., Guo, H., Yi, Y., \& Liu, Y. 2010. Ownership concentration and product innovation in Chinese firms: The mediating role of learning orientation. Management and Organization Revieze, 6(1): 77-100.

Liu, H., Lu, Y., \& Song, L. 2009. Tunneling of large shareholders: Co-monitoring or competitive colluding? China Accounting Revieze, 7(1): 97-112 (in Chinese).

Luo, J.-H., Wan, D.-F., \& Cai, D. 2012a. The private benefits of control in Chinese listed firms: Do cash flow rights always reduce controlling shareholders' tunneling? Asia Pacific Journal of Management, 29(2): 499-518.

Luo, Y., Huang, Y., \& Wang, S. L. 2012b. Guanxi and organizational performance: A meta-analysis. Management and Organization Review, 8(1): 139-172.

Luo, Y., \& Peng, M. W. 1999. Learning to compete in a transition economy: Experience, environment, and performance. Journal of International Business Studies, 30(2): 269296.

March, J. 2005. Parochialism in the evolution of a research community: The case of organization studies. Management and Organization Reviez, 1(1): 5-22.

Maury, B., \& Pajuste, A. 2005. Multiple large shareholders and firm value.Journal of Banking \& Finance, 29(7): 1813-1834.

Morck, R., Wolfenzon, D., \& Yeung, B. 2005. Corporate governance, economic entrenchment, and growth. Journal of Economic Literature, 43(3): 655-720.

North, D. C. 1990. Institutions, institutional change, and economic preference. New York: Norton.

North, D. C. 2005. Understanding the process of institutional change. Princeton, NJ: Princeton University Press.

Ostrom, E. 2005. Understanding institutional diversity. Princeton, NJ: Princeton University Press. 
Pagano, M., \& Rocll, A. 1998. The choice of stock ownership structure: Agency costs, monitoring, and the decision to go public. Quarterly Joumal of Economics, 113(1): 187-225.

Pan, H., \& Yu, M. 2010. Soft budget constraint and expropriation: Evidence from privately-ozened firms in China. CFRN Working Paper. Wuhan, China: Economics and Management School, Wuhan University.

Peng, M. W. 2003. Institutional transitions and strategic choices. Academy of Management Review, 28(2): 275-296.

Peng, M. W. 2004. Outside directors and firm performance during institutional transitions. Strategic Management Journal, 25: 453-471.

Peng, M. W., \& Jiang, Y. 2010. Institutions behind family ownership and control in large firms. Journal of Management Studies, 47(2): 253-273.

Peng, M. W., Sun, S. L., Pinkham, B., \& Chen, H. 2009. The institution-based view as a third leg for a strategy tripod. Academy of Management Perspectives, 23(3): 63-81.

Peng, M. W., Zhang, S., \& Li, X. 2007. CEO duality and firm performance during China's institutional transitions. Management and Organization Revieze, 3(2): 205-225.

Rozeff, M. S. 1982. Growth, beta and agency costs as determinants of dividend payout ratios. Joumal of Financial Research, 5(3): 249-259.

Shleifer, A., \& Vishny, R. 1997. A survey of corporate governance. Joumal of Finance, 52(2): 737-783.

Su, Y., Xu, D., \& Phan, P. H. 2008. Principal-principal conflict in the governance of the Chinese public corporation. Management and Organization Revieze, 4(1): 17-38.

Suhomlinova, O. 2006. Towards a model of organizational co-evolution in transition economics. Joumal of Management Studies, 43(7): 1537-1558.

Tan, J., \& Peng, M. W. 2003. Organizational slack and firm performance during cconomic transitions: Two studies from an emerging economy. Strategic Management Journal, 24(13): 1249-1 263.

Tian, L., \& Estrin, S. 2008. Retained state shareholdings in Chinese PLCs: Does government ownership always reduce corporate value? Joumal of Comparative Economics, 36(1): 74-89.

Tsui, A. S. 2006. Contextualization in Chinese management research. Management and Organization Review, 2(1): 1-13.

Villalonga, B., \& Amit, R. 2006. How do family ownership, control and management affect firm valuc? Joumal of Financial Economics, 80(2): 385-417.

Wang, Q., Wong, T. J., \& Xia, L. 2008. State ownership, the institutional environment, and auditor choice: Evidence from China. Joumal of Accounting and Economics, 46(1): 112-134.

Wright, M., Filatotchev, I., Hoskisson, R., \& Peng, M. W. 2005. Strategy research in emerging cconomies: Challenging the conventional wisdom. Journal of Management Studies, 42(1): $1-33$.

Yeh, Y. 2005. Do controlling shareholders enhance corporate value? Corporate Governance: An International Revieze, 13(2): 313-325.

Yoshikawa, T., Phan, P. H., \& David, P. 2005. The impact of ownership structure on wage intensity in Japanese corporations. Journal of Management, 31(2): 278-300.

Yoshikawa, T., \& Rasheed, A. A. 2010. Family control and ownership monitoring in familycontrolled firms in Japan. Journal of Management Studies, 47(2): 274-295.

Young, M. N., Peng, M. W., Ahlstrom, D., Bruton, G. D., \& Jiang, Y. 2008. Corporate governance in emerging economies: A review of the principal-principal perspective. Journal of Management Studies, 45(1): 196-220.

Zwicbel, J. 1995. Block investment and partial benefits of corporate control. Revieze of Economic Studies, 62(2): 161-185. 
Jin-hui Luo (jinhuiluo@xmu.edu.cn) is an assistant professor of accounting at the School of Management, Xiamen University. He received his Ph.D. in Management through Xi'an Jiaotong University. His research interests focus on corporate governance and corporate finance, especially family business management and governance. He has published many articles in leading Chinese academic journals and in the Asia Pacific Joumal of Management, Asian Business \& Management, Corporate Governance: The International Journal of Business in Society, and China Finance Review International.

Di-fang Wan (dfwan@mail.xjtu.edu.cn) is a professor of organization management at the School of Management, Xi'an Jiaotong University. He received his $\mathrm{Ph} . \mathrm{D}$. in Management through Xi'an Jiaotong University/University of Alberta joint Ph.D. program under the Canada-China Management Education Project. His research interests include corporate governance and corporate finance. He has published in the Asia Pacific Joumal of Management, Management and Organization Reviewe, Joumal of High Technology Management Research, among others.

Di Cai (xjtucd@stu.xjtu.edu.cn) is a Ph.D. candidate at the School of Management, Xi'an Jiaotong University. His research interests focus on corporate governance and corporate finance. He has published several articles in leading Chinese academic journals and in the Asia Pacific Joumal of Management and Chinese Management Studies.

Heng Liu (liuheng8@mail.sysu.edu.cn) is an assistant professor of management at the Lingnan College, Sun Yat-sen University, and the corresponding author of this paper. He received his Ph.D. degree in Management through Xi'an Jiaotong University. His research focuses on strategic management and organization learning. He has published many articles in leading Chimese academic journals and in the Journal of Operations Management, Asia Pacific Journal of Management, and Asian Business \& Management.

Manuscript received: May 20, 2010

Final version accepted: October 10, 2012

Accepted by: Yadong Luo 